\title{
Promoting Botanical Literacy with a Mobile Application - CampusFlora - Using an Interdisciplinary, Students-as-Partners Approach
}

\author{
Richard Dimon, Lachlan Pettit, Caroline Cheung, and *Rosanne Quinnell' \\ School of Life and Environmental Sciences, Faculty of Science, University of Sydney, Australia
}

Contact: rosanne.quinnell@sydney.edu.au

\section{ABSTRACT}

In this article, we describe our students-as-partners process for bringing undergraduate and academic staff together to develop a mobile application (app) CampusFlora - for use across our campuses. Our project at the University of Sydney, Australia, was conceived as a way to improve the botanical literacy of biology students by engaging undergraduates to develop online maps of plant locations coupled with information relevant to biology curriculum. Through continuous improvements to the CampusFlora app system, we have expanded the user-base well beyond the life science student cohorts and now offer content that embraces cultural competence and organisational health initiatives. We offer reflections from student and staff partners on the project that highlight the value of the students-as-partners approach, and the potential value of establishing student partnerships across disciplines, across institutions, and into the community at large.

\section{KEYWORDS}

Students as Partners, CampusFlora, mobile applications, higher education, botanical literacy, plant blindness

The Students as Partners ( $\mathrm{SaP}$ ) model has continued to increase in popularity, fostering learning relationships between academic staff and students through the acquisition of valuable enquiry-led research experiences (Healey, Flint, \& Harrington, 2016; Pauli, Raymond-Barker, \& Worrell, 2016). Engaging student learning through research experience is an influential approach to understanding the teaching and practice of science (Healey et al., 2016; Hunter, Laursen, \& Seymour, 2007). The experiences students gain through the collaboration process of effective project partnership can be as important as the final research product (Cook-Sather, Bovill, \& Felten, 2014; Crawford, Horsley, Hagyard, \& Derricott, 2015). The SaP model affords opportunities for students to develop research practices and acquire valuable hands-on experience, ultimately creating authentic research outputs at curricular, pedagogical, or experimental design and analysis levels (Cook-Sather et al., 2014; Hunter et al., 2007). 
Recent students-as-partners projects have involved student collaborations at all levels of education, primary through tertiary (e.g., Davies, Measey, du Plessis, \& Richardson, 2016; Hemingway, Dahl, Haufler, \& Stuess, 2011; LeBard, Hibbert, \& Quinnell, 2017). Our focus is on the tertiary education sector, where undergraduates who conduct research with academic partners benefit intellectually, personally, and professionally (Hunter et al., 2007). The respective levels of responsibility that can be adopted by students and staff within a project has been identified as a limitation of student-staff collaborations (Bergmark \& Westman, 2016; Mercer-Mapstone et al., 2017). A more equitable balance of responsibility is more likely achieved when both academics and students start at the same level of expertise. In the case study we present in this article, student and academic researchers were considered equally technically literate, i.e., at a novice level with respect to mobile app development. This opened the possibility of students taking higher levels of shared responsibility for project development than they might otherwise have been able to if the staff members had already been experts (LeBard et al., 2017).

The SaP framework outlined by Healey et al. can be applied to interdisciplinary projects and "facilitate co-development of shared values" $(2016, p 3)$. According to Healey and colleagues, many student partnerships involve projects outside of the institutional curriculum, offering opportunities to enhance and develop skills within a transdisciplinary environment. Such collaborative approaches introduce academic mobility and networking for students (Mercer-Mapstone et al., 2017), providing rare and valuable learning experiences that are often difficult to offer within the university curriculum. Interdisciplinary partnerships provide unique perspectives for developing new and engaging educational products. In our experience, the development of our mobile biology learning tool has enabled interdisciplinary students-as-partners collaborations between computer science and non-computer-based scientific disciplines, offering novel pedagogical practices.

Enhancing student-faculty dialogue has been the focus of many students-as-partners approaches (Cook-Sather et al., 2014); however, few student-staff collaborations have been described within the biological sciences. Recent students-as-partners initiatives within biology have involved students collaborating to design and recreate teaching strategies for curricular activities, e.g., updating pedagogy strategies to laboratory classes (Andrews et al. 2017; Border, 2017). The remit for the partnership described here was to offer learning opportunities beyond the constraints of the formal curriculum. This project is focused on the discipline of botany, where, due to decreases in the amount of time dedicated to teaching and learning about plants in the curriculum, botanical literacy is declining and, in turn, this is impacting communication and outreach in the botany and ecology (Kramer \& Havens, 2015). New and contemporary approaches are necessary to address the issue of "plant blindness" (Lewis-Jones, 2016; Wandersee \& Schussler, 2001) evident in both the scientific community and the general public. As defined by Wandersee and Schussler, plant blindness is the inability to notice plants and plant diversity in our environment, and this has led to a retractions of subjects such as Botany; less time spent studying plants exacerbates plant blindness.

Here we provide a case study for our students-as-partners initiative by showcasing the development process of our botanical mobile learning app, CampusFlora. We highlight the benefits, challenges, and future directions associated with its development. We also discuss incorporating student partnerships and mobile learning technology to enhance pedagogical practices at a university level. 


\section{DESCRIPTION OF CAMPUSFLORA}

The CampusFlora project was designed to reconnect the University of Sydney community to their natural environment by making knowledge about the plants on campus accessible. Users can access this knowledge via an app available on multiple platforms i.e. via any web browser, an iOS app available from the Apple App Store, or an android app available from the Google Play Store. All versions of the app employ interactive maps to deliver content (see Figure 1). Tertiary students can use CampusFlora to develop their scientific observational skills and reinforce key concepts in biology. Plant classification comes alive as users can follow what morphological features comprise a fern compared to a flowering plant and how the evolution of these groups aligns to geological periods. Dedicated trails in CampusFlora improve the way students can tackle difficult or abstract concepts as offered in the curriculum, such as how climate change is altering the timing of flowering and fruiting of species. The CampusFlora project page (https://campusflora.wordpress.com/) includes links to the apps and the source code, which are made available under OpenSource (GPLV3) licence agreements.

\section{Figure 1: Screenshots from the CampusFlora iOS application}
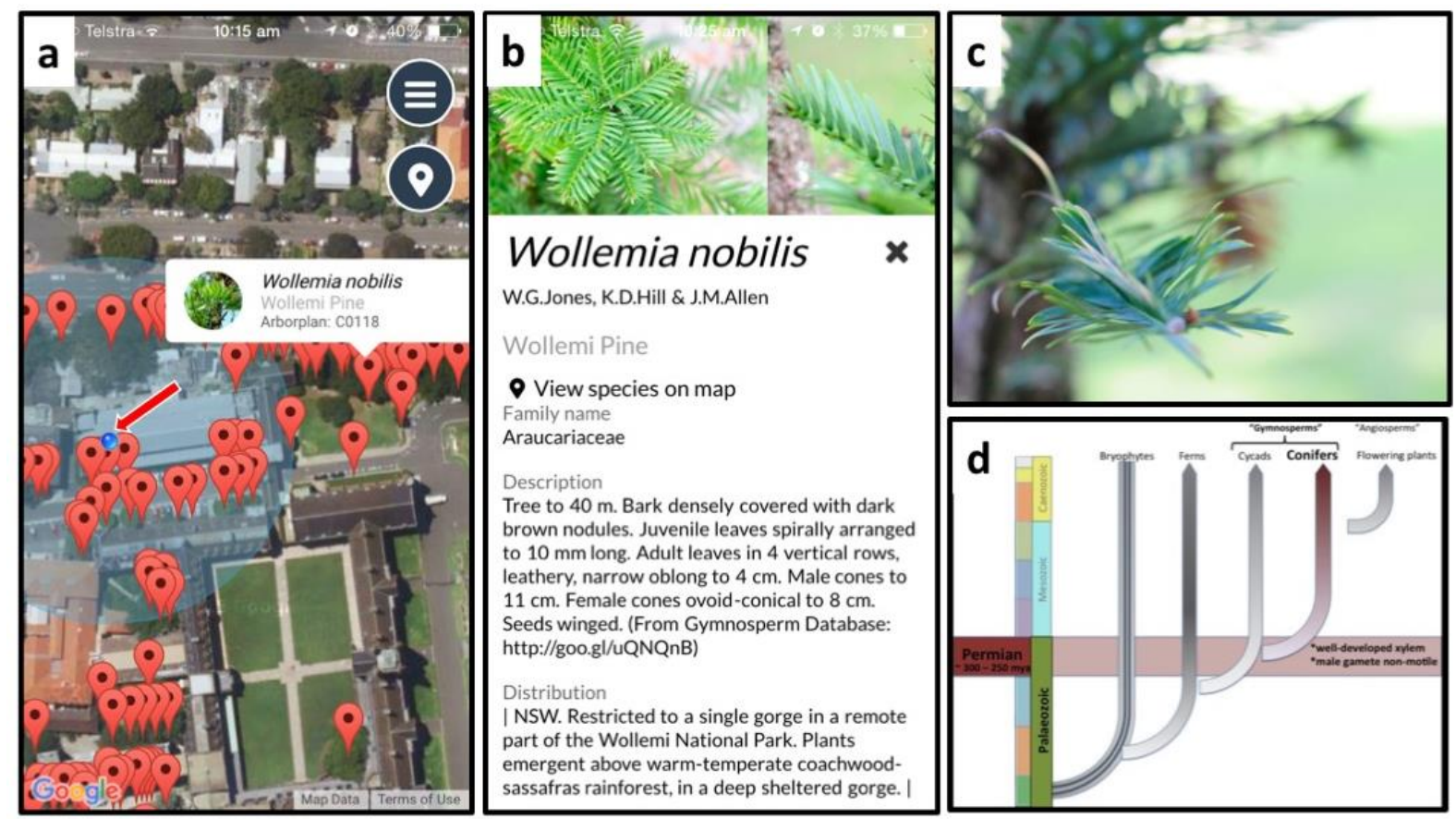

a) Homepage showing the user's location, indicated by a blue dot, and a tree location pin that, when selected as shown, displays image information, scientific and common name, and tree inventory number.

b) A plant information page, offered for each species, includes the scientific name, the formal plant description, and distribution.

c) An image of the plant (the bulk of the which were contributed by students) that visually supports the written morphological descriptions (e.g., that the leaves of the Wollemi Pine are distinctively arranged in four vertical rows.

d) A graphic that offers geological timelines and key evolutionarily derived characteristics of non-flowering plants: ferns and gymnosperms. 


\section{CAMPUSFLORA: A CASE STUDY}

The CampusFlora app was designed to enhance learning and teaching in botany, but has quickly extended beyond this remit. Since the development of the app prototype (Lachlan, who is a co-author here and who was an undergraduate Botany student in 2013), the project has become an effective network of students, academic staff, professional staff, and volunteers. Combined, the students-as-partners process and the software, offered under a Creative Commons licence, has proved a novel and appealing way to integrate botanical, ecological and cultural information.

The CampusFlora project has fostered student collaboration and has strong alignment with the SaP framework (Healey, Flint, \& Harrington, 2014). We emphasise how the project engages students as co-researchers partnering on scholarly enquiry and as learning resource co-designers. This collaborative approach achieves quality enhancements to student learning experiences with a focus on interdisciplinary learning spaces. The various student partnerships associated with CampusFlora cover all major aspects of a SaP model as described by Healey et al. (2016). These include student engagement in learning, teaching, and research, as well as incorporating students as change agents.

\section{Co-researching and co-enquiry}

Connecting students with scholarly literature was critical from the outset of this project and we used project frameworks from science education, specifically those formally and informally addressing botanical literacy (e.g., Hemingway et al., 2011; Mathes, 1983; Wandersee \& Schussler, 2001), the use of emerging technologies in teaching focused on mobile learning (Traxler, 2010), and the SaP literature. The primary aim of the CampusFlora project was to develop mobile learning resources that support biology students in engaging with the plants they see around them every day, and to engage with informal learning outside of formal classes (Halliday-Wynes \& Beddie, 2009). We achieved this aim by fostering a practice of informal learning for Life Science students through exploiting our reliance on mobile technology (Afreen, 2014). Students-as-partners approaches position students and teachers in a shared educational space for adopting new technologies in learning and teaching, and in our project, students and staff brought to the project diverse and valuable perspectives. The project has highlighted the extensive living plant collection available for study across all of the University of Sydney campuses. Therefore, the living botanical learning space available for students, for the campus community, and for visitors has vastly expanded and improved botanical awareness (Cheung, Wardle, \& Quinnell, 2015).

Key outcomes for CampusFlora student partners have been the opportunity to coauthor academic publications and to co-present the project. Ten undergraduate students have either co-authored articles or presented talks about CampusFlora, both within the institution and at national and international conferences. Their presentations have included fora relating to: science and engineering education, higher education more generally, and to groups of visiting scholars.

\section{Co-designing and co-developing learning resources}

Developing the app put both students and staff on technical and creative learning curves in terms of structuring the database and user interface. The CampusFlora project has been in place for five years, and over this time undergraduate students from a range of disciplines have partnered at various stages of design, development, and deployment. Student partners from Botany, Ecology, and Engineering contributed key developmental 
inputs. A handful of students approached Rosanne (academic staff) to volunteer on this project; others' contributions have been part of students' assessable work (e.g., advanced Faculty of Science program and the Summer Scholars program, both aimed at encouraging our 'best and brightest'). As students have moved towards graduation and their careers, the composition of the project team has changed. Regardless, all team members become familiar with the literature on the impact of new and emerging technologies in learning and teaching (e.g., Rifkin, Longnecker, Leach, \& Davis, 2011).

Biology student partners have acquired professional skills through photography, database maintenance, and the research, design, and implementation of botanical walking trails. These students became experts in the applied botanical content, as well as educational design. This is evident through specially designed CampusFlora trails that provide easy access to observe and study living plant material around our campus.

The combination of students' technological expertise (e.g., our collaboration with engineering students) with pedagogical practices creates a successful framework for partnership between faculty and students, overcoming limitations between interdisciplinary education and connectivity (Spector, 2015; Zhu \& Baylen, 2005). Students in the Faculty of Engineering enthusiastically developed the Android version of CampusFlora indicating the project's interdisciplinary appeal for students. These seven Engineering students and Caroline, presented their work at a University of Sydney educational showcase.

Additional project developments have expanded into disciplinary areas outside of Western science, i.e., the arts and music, cultural competence, and organisational health initiatives (see Figure 2). A serendipitous offshoot of the CampusFlora project was in the discipline of music composition, where elements of the CampusFlora app like images and text-based descriptions were rendered as soundscapes (Frame, 2016). Co-development by Healthy Sydney University's "Move More, Sit Less" group resulted in the creation of "walking meeting" trails in CampusFlora to encourage members of our university community to adopt healthier practices and to engage with our botanical resources. With support from the Deputy Vice-Chancellor, Indigenous Services and Strategy portfolio, the app now provides ethnobotanical aboriginal teachings by providing names of selected trees in appropriate Aboriginal languages (Quinnell, Troy, \& Poll, 2018; Troy, 1994). Expertise from CampusFlora is being applied in other students-as-partners development projects in the Faculty of Agriculture (e.g., Henson et al., 2017). 


\section{Figure 2: CampusFlora app development pathway over five years}

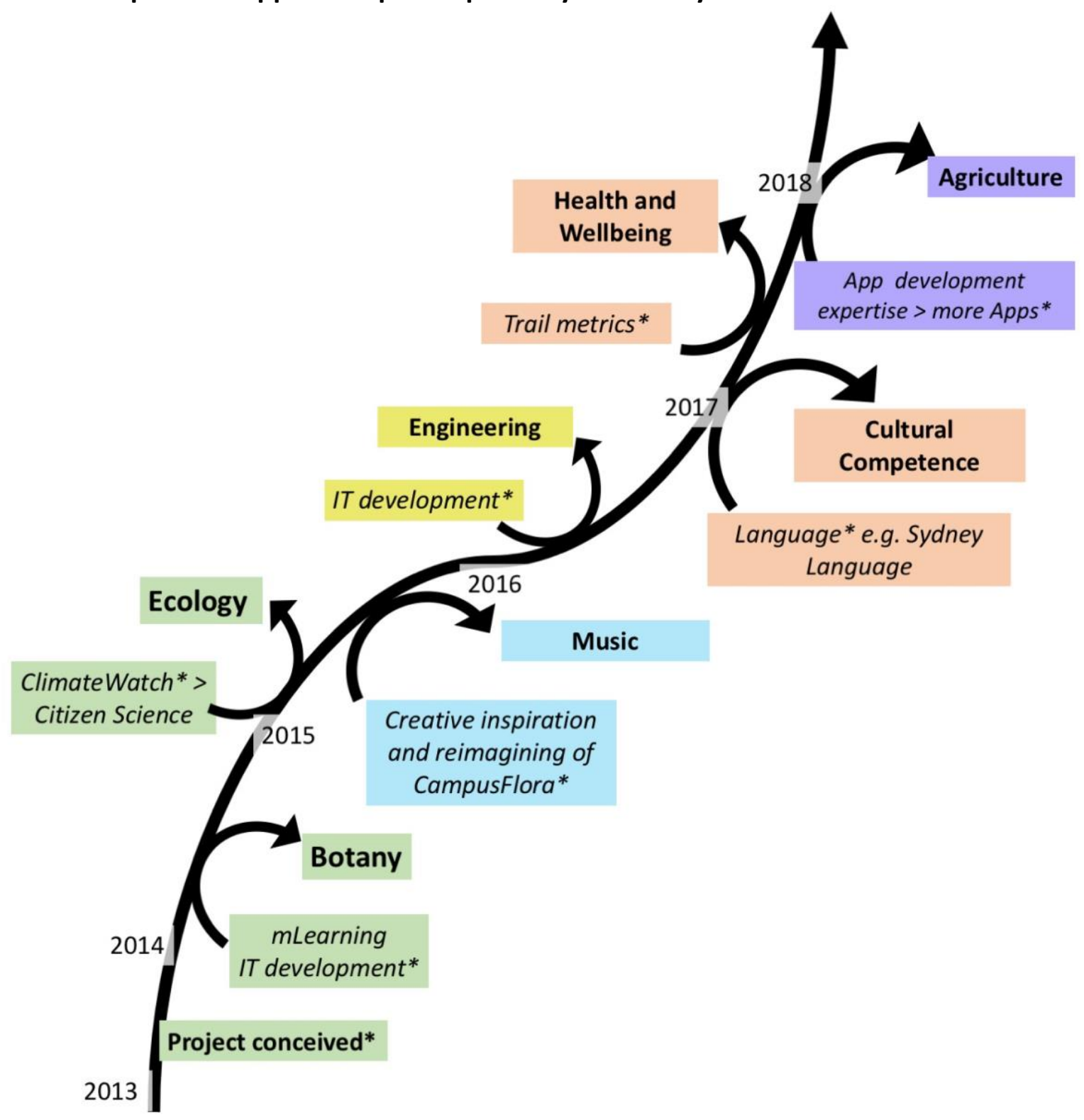

App development included undergraduate partners (indicated by asterisks) from Botany, Ecology, and Engineering. CampusFlora content aligned to the undergraduate Life Science curriculum in Botany and Ecology (2014-current). Botanical content has inspired Music Composition; and, further enhancements (2017-2018) have made CampusFlora a useful Cultural Competence and Health and Wellbeing engagement tool for the campus community. A students-as-partners approach is being used in Agriculture to develop apps for farmers. Graphic: R. Quinnell.

\section{Reflections on CampusFlora student-staff partnerships}

The enthusiasm and unique interests of undergraduate student partners have driven the CampusFlora project. Three of the primary student partners collaborating on this project, who are also co-authors of this article, offered reflective statements regarding the impacts of working in partnership to develop CampusFlora. These students acknowledged the overall benefits of being allowed to operate outside of the confines of the curriculum, unlike in a typical classroom learning environment. 
Caroline was a student partner on the CampusFlora project during her summer scholarship in 2015 and continued to work on the project during the remainder of her undergraduate studies. She reflected:

As a student partner and collaborator on the CampusFlora project, I was able to engage in meaningful learning experiences through authentic self-learning outside of the confines of the curriculum. Working in interdisciplinary teams helped me develop not only industry-relevant skills, both specific and technical, such as mapping and plant identification, but also more broadly transferable skills, e.g., networking, cultural competencies, and communication skills, from firsthand experience.

There were striking similarities in students' statements that highlighted the uniqueness of this project for "building new skills in research and science communication", as co-author and student partner Lachlan commented, including gaining experience in publishing. There was strong consensus that this project provided opportunities to develop authentic, industry-ready skills in collaboration and networking by being able to take interdisciplinary and culturally-competent approaches.

Lachlan worked on CampusFlora during a second-year Advanced Botany project in 2013 and during his summer scholarship in 2014. He commented:

CampusFlora provided a fantastic platform for developing collaborations and building new skills in research and science communication. It was a unique experience for me as a botany student to help develop a tool that aims to improve botanical literacy. It continues to be exciting seeing the growth and evolution of CampusFlora as new collaborations take the project down unexpected paths.

The involvement and support of the University community at large has been crucial for the success of the CampusFlora Project. As a case in point, the support of the Healthy Sydney University network enabled us to offer something of value to our campus community by encouraging participation in healthier lifestyle choices. This was coupled with a unique opportunity for an undergraduate student partner to collaborate with professional staff.

Richard was an undergraduate botany student who worked on the Healthy Sydney University project in 2017 to expand the remit of the CampusFlora app for the "Move More, Sit Less" group:

Working with CampusFlora has allowed me to collaborate with many university staff and students, providing valuable networking and communication skills across multiple disciplines. Participating in such a diverse project has allowed me to gain firsthand experience of the benefits provided by student-staff partnerships. The unique opportunity to enhance my skills in scientific research and publication is incomparable to the typical classroom learning experience.

At the outset, we were completely new to app development, but we had a shared optimism and excitement about making a botanical teaching application. Extending the partnership to include students from the Faculty of Engineering resulted in improved processes for upkeep of the CampusFlora database. That we (the student partners and Rosanne, the faculty partner in biology) were all at the same level of digital literacy and 
expertise prior to the start of the project arguably made the adoption of the SaP model less problematic. The influences of biology students have manifested at all stages of planning, communication, and maintenance of the CampusFlora project. In having equivalent expertise, there was no novice-expert barrier, and the confidence of the biology student partners allowed them to assume leadership roles, liberating Rosanne to participate as an authentic member of the project team.

The reflective statement provided by Rosanne, the fourth author and academic staff lead on this project, complements the commentary from students and highlights the positive effect student-driven initiatives had on this project:

I have learnt that by reframing my role with students as a collaborator, rather than a teacher, great things can happen. Largely this project has operated outside of the curriculum which, on the one hand, freed us from the strictures of formal assessment and the constraints of the semester timeline, but on the other hand, impacted on resources (primarily time) available to commit to this project. That I have been able to co-create a botanical app with my students that has appealed to the campus community (at large) is up there as one of my greatest achievements as an educator.

\section{Quality enhancement of learning and research}

That the CampusFlora initiative is a mobile one places opportunities to learn about plants literally at users' fingertips and shifts teaching beyond the constrained classroom timetable. The impact and influence of the CampusFlora app innovation has grown beyond our original vision. To date, there have been close to 6000 CampusFlora users, comprising $2200+$ Web users, 3550+ iOS downloads, and 350+ Google Play Store downloads. This exceeds by a factor of about 20 the roughly 100 students enrolled in Intermediate Botany each year for the last three years and indicates that our reach is well beyond the original target audience. In particular, we wish to note that many users are located outside of Australia. CampusFlora has been incorporated into student-driven projects that investigate phenology (flowering and fruiting) and upload their observations into the ClimateWatch citizen-science network (Earthwatch Australia, 2010). CampusFlora has supported more robust participation in citizen science for ecology students by improving the accuracy of identification of plants and their morphological characteristics (Cheung et al., 2015). PhD students are adapting CampusFlora for use in their own research in new and exciting ways, e.g., to locate colonies of social insects that reside on specific host plants; and undergraduate students have utilised CampusFlora to locate trees as the start-point for their research investigations.

\section{FUTURE DIRECTION AND PARTNERSHIPS}

Students-as-partners approaches challenge student-teacher and novice-expert binaries. Without the traditional power strictures that come with these binaries (CookSather \& Felten, 2017), students have room to grow their confidence and more readily offer ideas into the project space. The end goal of our project is to enable other students-aspartners projects to create blended botanical-social narratives using the CampusFlora system, and we are in a position to offer advice and guidance on how others may craft and share their own experiences.

Passion and commitment for this project has taken us a long way. However, as with all educational innovations, particularly technology-focused projects, sustainability is a concern. 
Certainly, as a model for students-as-partners projects, co-creating mobile apps energises and focuses all partners. There is potential for expansion; however, institutional commitment to secure longevity of technologically-innovative projects is essential.

\section{ACKNOWLEDGEMENTS}

We are grateful of the opportunity to participate in the prestigious national program, Commonwealth Scientific and Research Organisation's ONPRime (2017) for "new ideas ready to break out".

\section{NOTE ON CONTRIBUTORS}

Richard Dimon worked on this project in 2017/2018 and in addition to adding distance metrics to trails, he mapped the plants at our field-station, Pearl Beach, NSW and he designed the health promotion trails. Richard is currently working as a research assistant in the Orchid Conservation Project at the Royal Botanic Gardens Victoria.

Lachlan Pettit worked on this project as an undergraduate student in the Advanced Botany unit of study in 2013 and a Summer Scholar in 2014. Lachlan co-designed the user interfaces for the three app platforms of CampusFlora. Lachlan contributed many of the photographs in CampusFlora. He is currently undertaking a PhD in ecology in the School of Life and Environmental Sciences at the University of Sydney.

Caroline Cheung worked on this project as Summer Scholar in 2015 and was a student participant during CSIRO's ONPrime mentoring program in 2017. Caroline co-designed the user interfaces for the three app platforms the CampusFlora and crafted the ClimateWatch trail. She continues to be a passionate science educator and communicator and is currently working as a Visitor Experience Officer at the Australian Museum and also as an Education Officer for Sydney Water.

Rosanne Quinnell is an Associate Professor in the School of Life and Environmental sciences. She is committed to best practice in the use of new and emerging learning technologies, and champions botanical literacy. \#iamabotanist

\section{REFERENCES}

Afreen, R. (2014). Bring your own device (BYOD) in higher education: Opportunities and challenges. International Journal of Emerging Trends \& Technology in Computer Science, 3(1), 233-236.

Andrews, R., Grondin, M., Albano, Y., El-Abed, Y., Donaldson, C., Bondy, M., \& CavalloMedved, D. (2017). Developing cancer biology pedagogy through student-faculty partnerships. Paper presented at the UWill Discover Undergraduate Conference, University of Windsor, Windsor, Ontario, Canada. Retrieved from: https://scholar.uwindsor.ca/uwilldiscover/2017/session9/1 
Bergmark, U., \& Westman, S. (2016). Co-creating curriculum in higher education: Promoting democratic values and a multidimensional view on learning. International Journal for Academic Development, 21(1), 28-40.

Border, S. (2017). Working with students as partners in anatomy education. Anatomical Sciences Education, 10(6), 613-614.

Cheung, C., Wardle, G., \& Quinnell, R. (2015). CampusFlora: A digital education and engagement tool to turn whole campuses into interactive learning spaces. Bulletin of the Ecological Society of Australia, 45(3), 15-19. Retrieved from www.ecolsoc.org.au/files/bulletins/esa-october-bulletin-2015.pdf

Cook-Sather, A., Bovill, C., \& Felten, P. (2014). Engaging students as partners in learning and teaching: A guide for faculty. Jossey Bass. San Francisco.

Cook-Sather, A., \& Felten, P. (2017). Ethics of academic leadership: Guiding learning and teaching. In F. Su \& M. Woods (Eds.), Cosmopolitan perspectives on academic leadership in higher education (pp. 175 - 191). London, UK: Bloomsbury.

Crawford, K., Horsley, R., Hagyard, A., \& Derricott, D. (2015). Pedagogies of partnership: What works. Retrieved from: https://www.heacademy.ac.uk/knowledgehub/pedagogies-partnership-what-works

Davies, S. J., Measey, G. J., du Plessis, D., \& Richardson, D. M. (2016). Science and education at the Centre for Invasion Biology. In P. Castro, U.M. Azeiteiro, P. Bacelar-Nicolau, W. Leal Filho and A.M. Azul (Eds.), Biodiversity and education for sustainable development. World Sustainability Series. (pp. 93-105): Springer International Publishing: Cham.

Earthwatch Australia. (2010). Climatewatch. Retrieved from www.climatewatch.org.au

Frame, C. (2016). Botanical Sonification Toolbox (BOTSOT). Retrieved from http://www.ciaranframe.com/botsot/

Halliday-Wynes, S., \& Beddie, F. (2009). Informal learning at a glance. Retrieved from https://files.eric.ed.gov/fulltext/ED507131.pdf

Healey, M., Flint, A., \& Harrington, K. (2014). Engagement through partnership: Students as partners in learning and teaching in higher education. Retrieved from Higher Education Academy website: https://www.heacademy.ac.uk/engagement-through-partnershipstudents-partners-learning-and-teaching-higher-education

Healey, M., Flint, A., \& Harrington, K. (2016). Students as Partners: Reflections on a conceptual model. Teaching \& Learning Inquiry, 4(2), 1-13.

Hemingway, C., Dahl, W., Haufler, C., \& Stuess, C. (2011). Building botanical literacy. Science, 331(6024), 1535-1536.

Henson, Y., Martin, R. J., Quinnell, R., Van Ogtrop, F., Try, Y., \& Tan, D. (2017). Development of a weed identifier mobile application for Cambodian rice farmers. Proceedings of the 18th Australian Society of Agronomy Conference. Retrieved from http://www.agronomyaustraliaproceedings.org/images/sampledata/2017/21 ASA201 7 Yehezkiel Henson FinalL.pdf

Hunter, A. B., Laursen, S. L., \& Seymour, E. (2007). Becoming a scientist: The role of undergraduate research in students' cognitive, personal, and professional development. Science Education, 91(1), 36-74.

Kramer, A. T., \& Havens, K. (2015). Report in brief: Assessing botanical capacity to address grand challenges in the United States. Natural Areas Journal, 35(1), 83-89.

LeBard, R., Hibbert, D.B., \& Quinnell, R. (2017). Using new technologies for science teaching: Investigating best practice in digital research spaces to engage students with eScience. Teaching Science, 63(1), 41-48. 
Lewis-Jones, K. E. (2016). People and plants. Environment and Society, 7(1), 1-7. Retrieved from https://www.berghahnjournals.com/downloadpdf/journals/environment-andsociety/7/1/air-es070101.xml

Mathes, M. C. (1983). Fostering botanical literacy. Bioscience, 33(8), 479-479.

Mercer-Mapstone, L., Dvorakova, S. L., Matthews, K., Abbot, S., Cheng, B., Felten, P., Knorr, K., Marquis, E., Shammas, R., \& Swaim, K. (2017). A systematic literature review of Students as Partners in higher education. International Journal for Students as Partners, 1(1), 1-23.

Pauli, R., Raymond-Barker, B., \& Worrell, M. (2016). The impact of pedagogies of partnership on the student learning experience in UK higher education. Retrieved from Higher Education Academy website:

https://www.heacademy.ac.uk/system/files/impact of pedagogies of partnership.pd $\underline{f}$

Pettit, L., Pye, M., Wang, X., \& Quinnell, R. (2014a). Designing a bespoke app to address botanical literacy in the undergraduate science curriculum and beyond. In B. Hegarty, J. McDonald, \& S.-K. Loke (Eds.), Rhetoric and Reality: Critical perspectives on educational technology. Proceedings ascilite Dunedin 2014 (pp. 614-619). Retrieved from ascilite website:

http://www.ascilite.org/conferences/dunedin2014/files/concisepapers/214-Pettit.pdf

Pettit, L., Pye, M., Wang, X., \& Quinnell, R. (2014b). Supporting botanical literacy in the undergraduate science curriculum and beyond with a bespoke campus app. 20th Annual Australian Conference on Science and Mathematics Education, University of Sydney, Sydney, Australia University Sept 29th to Sept 30th , 2014, p 71, Retrieved from https://openjournals.library.sydney.edu.au/index.php/IISME/article/download/7719/8 $\underline{481}$

Quinnell, R., Troy, J., \& Poll, M. (2018, April). The Sydney Language in our curriculum. Paper presented at the Cultural Competence and the Higher Education Sector: Dilemmas, Policies and Practice, Sydney, Australia.

Rifkin, W., Longnecker, N., Leach, J., \& Davis, L. (2011). Worried about engagement? Have students create "New Media". Proceedings of the Australian Conference on Science and Mathematics Education, 211-219. Retrieved from https://openjournals.library.sydney.edu.au/index.php/IISME/article/view/4797/5584

Spector, J. M. (2015). Foundations of educational technology: Integrative approaches and interdisciplinary perspectives. Routledge.New York.

Traxler, J. (2010). Distance education and mobile learning: Catching up, taking stock. Distance Education, 31(2), 129-138.

Troy, J. (1994). The Sydney Language. Canberra, Australia: Panther Publishing and Printing. Retrieved from:

http://dalang.com.au/Dharug/reference/troy sydney language publication.pdf

Wandersee, J. H., \& Schussler, E. E. (2001). Toward a theory of plant blindness. Plant Science Bulletin, 47(1), 2-9.

Zhu, E. \& Baylen, D. M. (2005). From learning community to community learning: Pedagogy, technology and interactivity. Educational Media International, 42(3), 251-268. 